\title{
Marketing of Orange Fruit in Maiduguri Metropolitan Area, Borno State, Nigeria
}

\author{
Muhammad SaboTijjani $^{1^{*}} \quad$ Rahila Christopher Wakawa $^{2} \quad$ Mohammed Goni $^{3} \quad$ Alhaji Umar Bukar ${ }^{1}$ \\ 1.Department of Agricultural Technology, Ramat Polytechnic, P.M.B.1070, Maiduguri, Nigeria \\ 2.Science Policy and Innovation Studies Department (SPIS), National Centre for Technology Management \\ (NACETEM), Abuja, Nigeria \\ 3.National Agricultural Extension and Research Liaison Services Ahmadu Bello University, Zaria, Nigeria
}

\begin{abstract}
This study examined the marketing of orange fruit in Maiduguri. Primary data were obtained from the respondents with the use of structured questionnaires that were filled through interviews from 60 respondents. 30 wholesalers were randomly selected from the major wholesale market and 30 retailers, were also randomly selected, ten each from three different wards of the town. Descriptive statistics were used to analyze the socio-economic characteristics of the marketers as well as the problem associated with the orange fruit marketing. Gross margin analysis was used to determine the profitability of the marketing, while Gini coefficient was used to determine the degree of market concentration. The results show that all orange marketers were in their economically active age and are mostly males with very few educated up to tertiary level (ten percent). The cost and returns analysis showed that the gross margin per marketer per week for wholesalers is $\$ 228,500$, while for retailers is lower at $\$ 6,355$. However, the gross margin per kilogramme of 30 for the wholesale market is less than that for the retail market which stood at $41 / \mathrm{kg}$. The wholesale market has a high level of market concentration with a Gini coefficient of 0.813 , while the retail market has a lower degree of concentration with a coefficient of 0.466 . The markets therefore have monopolistic and oligopolistic tendencies respectively. Problems mentioned by the marketers include shortage of capital and storage facilities. The study therefore recommends that credit at favourable terms and modern storage facilities be provided to the marketers. This can enable them to expand their scale and possibly lower their cost. This could lead to lower prices to consumers and hence increased intake of orange fruits for better health outcomes.
\end{abstract}

Keywords: Orange, market channel, profitability, market structure

DOI: $10.7176 / \mathrm{JBAH} / 9-22-02$

Publication date: November $30^{\text {th }} 2019$

\section{Introduction}

Fruits provide an abundant and cheap source of fiber and several vitamins and minerals. In general they have the highest nutritional value when eaten fresh, although an exception may be fermented foods, in which the process of fermentation can increase the content of B vitamins. Fruits play a number of important roles in human health. They provide antioxidants such as vitamin A that are important in neutralizing free radicals (oxidants), known to cause cancer, cataracts, heart disease, hypertension, stroke and diabetes (Mintesnot 2016). Diets high in fruits are widely recommended for their health promoting properties. The major fruits produced in Nigeria include mango, pineapple, plantain/banana, citrus, guava and pawpaw.

The sub-genus Citrus (Swingle), family Rutaceae and subfamily Aurantioideae is of three types: Citrus, Fortunella (Kumquat) and Poncirus Trifoliata. There are three genera and eighteen defined species, but other natural mutations exist resulting to numerous hybrids which are widely spread throughout the world (Guo and Deng, 2001) in (Etebu and Nwauzoma, 2014) who further state that sweet orange (Citrus sinensis L. Osbeck), commonly called orange is a member of this family. Fakayode et.al, (2010) reported that sweet orange is one of the most important fruits in the tropical and sub-tropical regions of the world. The fruits are eaten fresh and used for making canned orange juice. Large quantities of sweet orange are used to produce single strength juice, frozen concentrate, rind oil, pectins used in the production of jams and jelly pulp residue which is fed to livestock. The orange juice is also extracted and used for flavours for food items. In Nigeria, the production of citrus fruits, with orange said to be the most important, rose from a million tons per annum in the early sixties to 4, 088, 994 tons in 2017( FAO, 2019).

More than three quarters of adults in less developed countries consume less than the minimum recommended five daily servings of fruit and vegetables. In sub-Saharan Africa the level of fruits is much less common and varies across countries. Also the average consumption (in kg per capita per year) is lower for fruits than vegetables in most countries (Ruel et. al, 2005). The authors further reported that consumption of both products is generally higher in urban areas compared to rural areas. Yahaya (2018), reported that even though fruit consumption has increased by approximately ten percent per year, per capita daily fruit juice intake in Nigeria is only $20 \mathrm{mg}$ compared to the recommended minimum requirement of $75 \mathrm{mg}$.

This low per capita consumption of fruits in many developing countries including Nigeria may be due to low 
awareness of their nutritive value or their high retail prices. The high prices are often blamed on middlemen who are accused of exploiting both fruit growers and consumers in fruit markets like that of Maiduguri. Such accusations tend to gain support whenever the marketing margin is high. However, such accusation may not be justified unless the costs and returns in marketing involved and other market characteristics are fully understood and properly estimated. To this effect this study aims at conducting ananalysis of Orange Fruit Marketing in Maiduguri. The main objective of the study is to conduct an analysis of the marketing of orange fruit in Maiduguri. The specific objectives of the study were to:

i. examine the socio-economic characteristics of the orange fruits marketers;

ii. examine the marketing channel for the orange fruits;

iii. determine the profitability of marketing orange fruits;

iv. determine the structure of orange fruit market; and

v. identify the problems associated with marketing of the orange fruits in the study area.

\section{Methodology}

\subsection{Study Area}

The study was conducted in Maiduguri, the capital of Borno State, Nigeria. It is located between latitudes $1142 \mathrm{~N}$ and $1200 \mathrm{~N}$ and longitudes 12.54 and $1314 \mathrm{E}$ and has a land area of $543 \mathrm{~km}^{2}$ (Haruna 2010) in (Ikusemoran and Jimme, 2014). The city is bounded in the north by Jere LGA, in the west, south and south-west by Konduga , in the north-west by Mafa LGA. Maiduguri has mean annual maximum temperature of 34.8 with mean (monthly) temperature ranging between 30 and $40 \mathrm{C}$. The city receives rainfall from June to September. However in rainy years, the city records rainfall earlier than June and latter than September. Being a nodal city, trading is the major occupation of the inhabitants with few agrarian practices (Ikusemoran and Jimme, 2014). It has a population of about 521,492 people which was projected to be 746,721 for 2019 based on an annual growth of 2.8\% (NPC, 2006). Maiduguri town is the largest in the north east geopolitical zone and lies in the Sudan Savannah ecological zone characterize by few trees and vast grass land.

\subsection{Source of Data}

Primary data and secondary information were used for the study. Primary data was obtained in 2018 from the respondents with the use of structured questionnaires that were filled through interviews. Secondary information was obtained from the internet and publications.

\subsection{Sampling Techniques}

Multi-stage sampling technique was used to collect data for the study. In the first stage, Gamboru Market was selected from Maiduguri. This market was purposely chosen because it is the major fruit wholesale market in the town. In the second stage, 30 wholesalers from the market were randomly selected. For the selection of retailers, three wards (Maisandari, Elkanemi and Bolori II Wards) were purposively selected due to the preponderance of orange retailers in the areas. 10 retailers were selected randomly from each ward. This gives a total of 30 wholesalers and 30 retailers, making a total of 60 respondents.

\subsection{Analytical Techniques}

2.4.1 Descriptive statistic

Descriptive statistics such as frequency tables and percentages was used to analyze the socio-economic characteristics of the marketers as well as the problem associated with the orange fruit marketing.

2.4.2 Gross Margin Analysis

This technique was used to determine the profitability of the marketing. This involved the analysis of the costs and return of orange fruit marketing. The gross margin is calculated as follows (Goni et.al, 2008):

$\mathrm{GM}=\mathrm{GI}-\mathrm{TVC}$

Where:

$\mathrm{GM}=$ Gross Margin (

$\mathrm{GI}=$ Gross income $(\#)$

TVC $=$ Total Variable Cost $(\mathrm{N})$

The gross margin was used because the fixed cost of most small scale agricultural operation is negligible.

2.4.3 Market Structure

The structure of the market was determined based on the finding on the market concentration.

2.4.3.1 Market Concentration

The Gini coefficient was used to determine the degree of market concentration of the sellers in the market. The Gini coefficient was computed using the following formula as used by Adinya et. al, (2007) and Goni et.al, (2008). $\mathrm{G}=1-\sum \mathrm{xy}$

Where $\mathrm{G}=$ Gini Coefficient 
$\mathrm{X}=$ Percentage share of each class of seller

$\mathrm{Y}=$ Cumulative percentage of their sales

The Gini Coefficient ranges from zero to one. It is a standardized coefficient such that zero implies perfect equality in earning, while coefficient of one means perfect inequality in earning. The closer the value is to unity (one), the greater is the degree of inequality and therefore, the higher is the level of concentration. Higher concentration signifies that a market is monopolistic in nature, with few individuals controlling it.

\section{Results and Discussion}

3.1 Socio-Economic Characteristic of Orange Fruit Marketers in Maiduguri

Table 1 shows that $(96.67 \%)$ of orange marketers in Maiduguri were males and they all fall within the economically active age of 15 to 60 years $(\mathrm{FAO}, 1992)$. The analysis of marital status shows that $(81.67 \%)$ are married, $(8.33 \%)$ single, $(8.33 \%)$ divorced and $(1.675 \%)$ widowed. In terms of educational status of the marketer's, the analysis shows that $36.6 \%$ had Islamic education, $28.33 \%$ had secondary education,

Table 1: Socio-Economic Characteristics of Orange Fruit Markets in Maiduguri $(n=60)$

\begin{tabular}{|c|c|c|}
\hline Characteristics & Frequency & Percentage (\%) \\
\hline \multicolumn{3}{|l|}{ Gender } \\
\hline Male & 58 & 96.67 \\
\hline Female & 2 & 3.33 \\
\hline \multicolumn{3}{|l|}{ Age group (years) } \\
\hline $20-29$ & 7 & 11.67 \\
\hline $30-39$ & 29 & 48.33 \\
\hline $40-49$ & 13 & 21.67 \\
\hline $50-59$ & 11 & 18.33 \\
\hline \multicolumn{3}{|l|}{ Marital Status } \\
\hline Married & 49 & 81.67 \\
\hline Single & 5 & 8.33 \\
\hline Divorce & 5 & 8.33 \\
\hline Widowed & 1 & 1.67 \\
\hline Other & 0 & 0 \\
\hline \multicolumn{3}{|l|}{ Educational Level } \\
\hline Primary Education & 10 & 16.67 \\
\hline Secondary Education & 17 & 28.33 \\
\hline Tertiary Education & 6 & 10.00 \\
\hline Islamic Education & 22 & 36.67 \\
\hline No Formal Education & 5 & 8.33 \\
\hline Total & 60 & 100 \\
\hline \multicolumn{3}{|l|}{ Household Size } \\
\hline $1-5$ & 25 & 41.67 \\
\hline $6-10$ & 20 & 33.33 \\
\hline $11-15$ & 9 & 15.00 \\
\hline $16-20$ & 6 & 10.00 \\
\hline \multicolumn{3}{|c|}{ Marketing Experience (Years) } \\
\hline $1-10$ & 23 & 38.33 \\
\hline $11-20$ & 22 & 36.67 \\
\hline $21-30$ & 6 & 10.00 \\
\hline $31-40$ & 8 & 13.33 \\
\hline $41-50$ & 1 & 1.67 \\
\hline$>50$ & 0 & 0.00 \\
\hline
\end{tabular}

Source: Field Survey, 2018.

$16.67 \%$ had primary education, $8.33 \%$ had no formal education with only $10 \%$ of the marketers educated up to tertiary level. $41.67 \%$ of the respondents have between $1-5$ household members; $33.33 \%$ claimed to have between 6-10 members; $15 \%$ and 10\% had between 11-15 and 16-20 members respectively. This reveals that respondent with large, medium and small household sizes were found in orange marketing in Maiduguri. Experience in marketing is a measure of the period an individual has been involved in the business/trading (Alufulai, et al, 2013). The analysis of the marketing experience revealed that appropriately $58.33 \%$ of the marketers have marketing experience of over 10 years. Hence they can be expected to use their experience to obtain higher profit. 


\subsection{Marketing Channel for Orange fruit In Maiduguri}

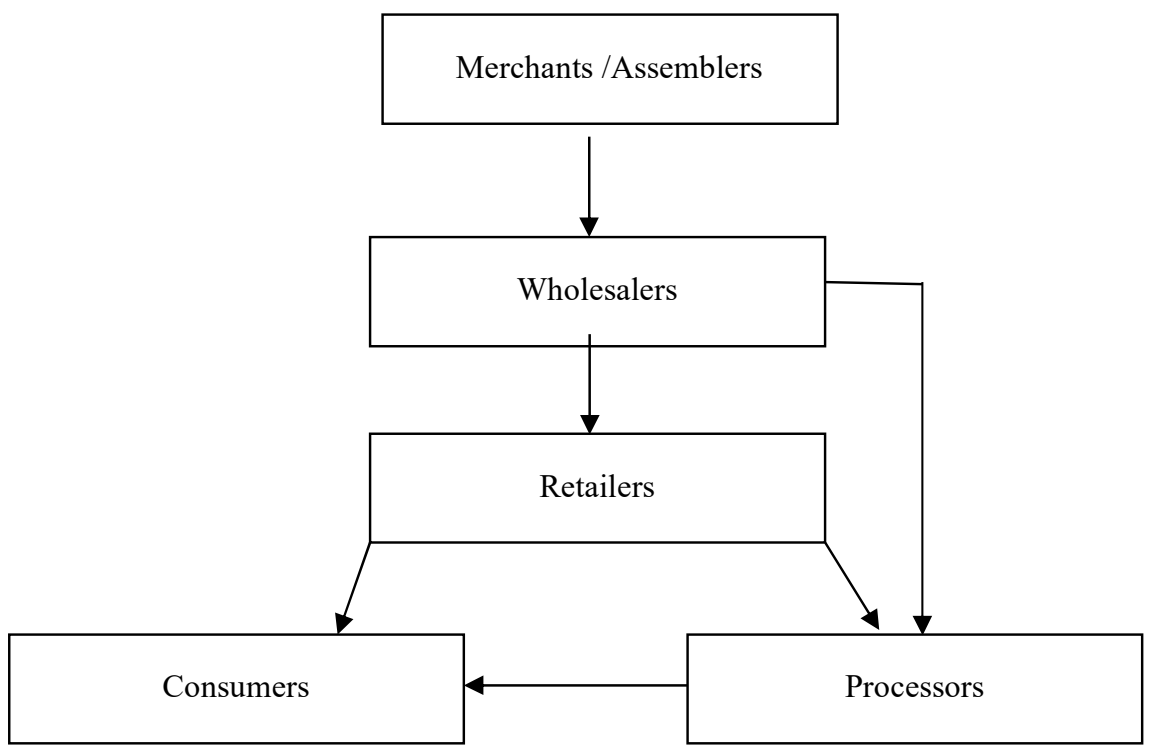

Figure 1: Marketing channel for orange fruit in Maiduguri.

The analysis of the marketing channel was intended to provide a systematic knowledge of the path which orange fruit follow, from point of production to the point of consumption. Along the channel are individuals who perform the physical functions in order to obtain economic benefit. Presented above (Figure 1) is the marketing channel for orange fruit in Maiduguri. It indicates that the merchants sell to wholesalers and wholesalers sell to both retailers and processors, while the retailers sell also to both consumers and processors as well.

\subsection{Profitability of Orange Fruit Marketing in Maiduguri}

In order to determine the profitability in marketing orange, the various costs incurred in process of the marketing were identified summed up and the total variable costs subtracted from the gross returns. Tables 2 and 3 present the gross margin per week of orange marketing in Maiduguri for both wholesale and retail marketing. The profitability analysis is important in order to form a basis for comparison for setting priorities and for ensuring that limited resources are invested in business that are worthwhile (Ahmed, 1978).

Table 2: Gross Margin of Wholesalers per Week of Orange Marketing in Maiduguri

Quantity of Orange Handled by all the Marketers

Average of Purchase Cost

Average Selling Cost

Transport Cost Incurred by all the Marketers

Total Variable cost of all the marketers

Gross income of all the marketers

Gross margin for all marketers

Gross margin per marketer

Gross margin per kg

Source: Field Survey 2018.

NB: The transport cost comprises of payment for loading and offloading and conveying to marketers' shed.

Table 3: Gross Margin for Retailers per Week of Orange Marketing in Maiduguri.

$\begin{array}{ll}\text { Quantity of Orange Handled by all the Marketers } & 4650 \mathrm{Kg} \\ \text { Average of Purchase Cost } & 170 / \mathrm{Kg} \\ \text { Average Selling Cost } & 216 / \mathrm{Kg} \\ \text { Transport Cost Incurred by all the Marketers } & 23,250.00 \\ \text { Total Variable cost of all the marketers } & 813,750.00 \\ \text { Gross income of all the marketers } & 1,004,400.00 \\ \text { Gross margin for all marketers } & 190,650.00 \\ \text { Gross margin per marketer } & 16355.00 \\ \text { Gross margin per kg } & \$ 41.00\end{array}$
$228500 \mathrm{Kg}$
$\$ 100 / \mathrm{Kg}$
N $170 / \mathrm{Kg}$
$\$ 9,140,000.00$
$¥ 31,990,000.00$
\# 38,845,000.00
N 6,855,000.00
\#228,500.00
$₫ 30.00$

Source: Field Survey 2018. 
NB: The transport cost comprises of payment for loading and offloading and conveying to marketers' shed.

This analysis revealed that the gross margin per marketer per week for wholesalers is $\$ 228,500$ with gross margin of $\$ 30 / \mathrm{kg}$, and for retailers is $\$ 6,355$ with gross margin of $\$ 41 / \mathrm{kg}$. This shows that orange marketing in Maiduguri is profitable.

3.4 Market Structure for Orange Fruit in Maiduguri

Table 4: Distribution of Marketers by Weekly Sales of Orange in Maiduguri

\begin{tabular}{|c|c|c|c|c|c|c|c|c|}
\hline $\begin{array}{l}\text { Quantity of } \\
\text { orange marketed } \\
\text { per week }(\mathrm{kg})\end{array}$ & $\begin{array}{l}\text { Mean } \mathrm{N} \\
(\mathrm{kg}) \text { of }\end{array}$ & $\begin{array}{l}\text { Tumber } \\
\text { sellers }\end{array}$ & $\begin{array}{l}\% \text { of } \\
\text { sellers } \\
(X)\end{array}$ & $\begin{array}{l}\text { Average } \\
\text { selling } \\
\text { price } \\
\text { per kg (\#) }\end{array}$ & $\begin{array}{l}\text { Total value } \\
\text { of sales ( })\end{array}$ & $\begin{array}{c}\% \text { of total } \\
\text { of sale }\end{array}$ & $\begin{array}{l}\text { Cumulative } \\
\% \text { of total }\end{array}$ & $\mathrm{XY}$ \\
\hline$\overline{5000-5,500}$ & 2,000 & 16 & 0.010 & 170 & $8,160,000$ & 0.020 & 0.020 & 0.002 \\
\hline $5551-10,500$ & $8,000.5$ & 5 & 0.003 & 170 & $6,800,425$ & 0.017 & 0.037 & 0.011 \\
\hline $10501-15500$ & $13,000.5$ & 6 & 0.002 & 170 & $13,260,510$ & 0.033 & 0.403 & 0.008 \\
\hline $15561-20,500$ & $18,000.5$ & 1 & 0.002 & 170 & $3,060,085$ & 0.007 & 0.410 & 0.082 \\
\hline $20,501-25,500$ & $23,000.5$ & 1 & 0.001 & 170 & $3,910,085$ & 0.009 & 0.419 & 0.041 \\
\hline $25,551-30,000$ & 27750.5 & 1 & 0.001 & 170 & $4,717,085$ & 0.011 & 0.430 & 0.043 \\
\hline Total & & 30 & & & $39,008,690$ & & & \\
\hline
\end{tabular}

Source: Field Survey, 2018.

$\mathrm{G}=1-\sum \mathrm{xy}=1-0.187=0.813$

Table 5: Distribution of Retail Marketers by Weekly Sales of Orange in Maiduguri.

\begin{tabular}{lcccccccc}
\hline $\begin{array}{l}\text { Quantity of } \\
\text { orange marketed } \\
\text { per week (kg) }\end{array}$ & $\begin{array}{c}\text { Mean } \\
(\mathrm{kg})\end{array}$ & $\begin{array}{c}\text { Number } \\
\text { of sellers }\end{array}$ & $\begin{array}{c}\% \text { of } \\
\text { sellers } \\
(\mathrm{X})\end{array}$ & $\begin{array}{l}\text { Average } \\
\text { selling } \\
\text { price } \\
\text { per kg (N) }\end{array}$ & $\begin{array}{c}\text { Total value } \\
\text { of sale (N) }\end{array}$ & $\begin{array}{c}\% \text { of total } \\
\text { of sale }\end{array}$ & $\begin{array}{c}\text { Cumulative } \\
\% \text { of total }\end{array}$ & XY \\
\hline $50-100$ & 25 & 12 & 0.400 & 216 & 194,400 & 0.222 & 0.222 & 0.089 \\
$101-150$ & 125.5 & 8 & 0.239 & 216 & 216,864 & 0.247 & 0.469 & 0.112 \\
$151-200$ & 175.5 & 4 & 0.171 & 216 & 151,632 & 0.173 & 0.642 & 0.109 \\
$201-250$ & 225.5 & 4 & 0.133 & 216 & 194,832 & 0.222 & 0.864 & 0.115 \\
$251-300$ & 275.5 & 2 & 0.109 & 216 & 119,016 & 0.132 & 1 & 0.109 \\
Total & 30 & & & 876,744 & & & 0.534 \\
\hline
\end{tabular}

Source: Field Survey, 2018.

$\mathrm{G}=1-\sum \mathrm{xy}=1-0.534=0.466$

The Gini coefficient of the marketers was found to be 0.813 for wholesalers (Table 4 ) while that of retailers was 0.466 (Table 5). The Gini coefficient of wholesalers tends toward one which shows that there is a high degree of inequality in earnings. This implies a high level of market concentration, which signifies that the market is monopolistic in nature. On the other hand, the Gini coefficient for retailers tends towards zero which implies that there is less inequality in earnings and hence a lower degree of market concentration compared to that of wholesalers. Based on a Gini coefficient cut-off point of 0.4 recommended by Parker and Connor (1979), the retail market has oligopolistic tendencies.

3.5 Problem Associated with Orange Fruit Marketing in Maiduguri

A number of problems are encountered by the marketers. Table 6 presents the different types of problems

Table 6: Problems of Orange Marketing in Maiduguri

\begin{tabular}{lll}
\hline Problems & Frequency & Percentage (\%) \\
\hline Insufficient capital & 54 & 90.00 \\
Lack of adequate storage facilities & 54 & 90.00 \\
Activities of middlemen & 52 & 86.67 \\
Exorbitant taxes & 29 & 48.33 \\
Total & 189 & 315 \\
\hline
\end{tabular}

Source: Field Survey, 2018

NB: Multiple responses existed, hence total succeeded 100.

encountered by marketers of orange fruit. The result of the study revealed that the major problem facing orange marketers in the study area were insufficient capital $90 \%$ and lack of adequate storage facilities $90 \%$, the third problem was activities of middlemen as revealed as $86.67 \%$ of the marketers. The problem also included exorbitant taxes of $48.33 \%$. This might be because of the presence of large number of security agencies along the high way. 


\section{Conclusion}

Findings from this study revealed that all orange marketers were in their economically active age and are mostly males with very few educated up to tertiary level. Orange marketing in Maiduguri was found to be profitable. The cost and returns analysis showed that the gross margin per marketer per week for wholesalers is $\$ 228,500$, while for retailers is lower at $\$ 6,355$. However, the gross margin per kilogramme of 30 for the wholesale market is less than that for the retail market which stood at $41 / \mathrm{kg}$. In terms of market structure, Gini coefficient for wholesalers was found to be 0.813 . This implies a high level of market concentration, hence the wholesale market can be said to be tending towards monopoly. On the other hand, the Gini coefficient for retailers was 0.466 . This tends towards zero which implies that there is less inequality in earnings and hence a lower degree of market concentration compared to that of wholesalers. Based on a Gini coefficient cut-off point of 0.4 recommended by Parker and Connor (1979), the retail market has oligopolistic tendencies. Although orange marketing in the study area was found to be profitable, it is bedeviled by shortage of capital and storage facilities. The study therefore recommends that credit at favourable terms and modern storage facilities be provided to the marketers. This can enable them to expand their scale and possibly lower their cost. This could lead to lower prices to consumers and hence increased intake of orange fruits for better health outcomes

\section{References}

Adinya I.B, Enya V.E and Kuye, O.O (2007) Structure ofTatura Goat Market. Obira L.G.A of Cross River State, Nigeria. Global Journal of Agricultural Science 6(1):55-59.

Ahmed, M. (1978). The Economic Analysis of Agricultural Projects Extension Bulletin No. 26. Agricultural

Extension and Research Liaison Services Ahmadu Bello University, Zaria, Nigeria.

Alufulai G.O, Ekuwe, P.AOrewa, S.I and Akpookah, E.V (2013) Socio-economic Factors Influencing Pineapple Marketing in Edo State Nigeria. Nigerian Journal of Agriculture, Food and Government 11(2): 87-91.

Etebu, E. and Nwauzoma, A. B. (2014) A review on sweet orange (Citrus Sinensis Osbeck): health, diseases, and management. American Journal of Research Communication. 2(2): 33-70

Fakayode, S.B., Omotesho, O.A., Babatunde, R.O. and Momoh, A.A. (2010) The Sweet Orange Market in Nigeria, How Viable? Research Journal of Agriculture and Biological Sciences, 6(4): 395-400.

Food and Agriculture Organization (FAO) (1992) Population, Education and Nutrition for Africa, Rome.

FAO (2019) FAOSTAT. http://www.fao.org/faostat/en/\#data/QC Accessed October 12, 2019.

Guo, W.W. and Deng, X. X. (2001) Wide somatic hybrids of Citrus with its related genera and their potential in genetic improvement, Euphytica 118, 175-183.

Haruna, T. (2010) Assessment of the structure of the unemployed in Maiduguri urban, Borno state. Unpublished B.Sc thesis, Department of Geography, Adamawa State University, Mubi.

Ikusemoran, M. and Jimme, A. M. (2014) A Decade Assessments of Maiduguri Urban Expansion (2002-2012): Geospatial Approach. Global Journal of Human-Social Sciencs:B Geography, Geo-sciences and Environmental Disaster Management. 14(2): 1-8

M.Goni, I.M. Sulumbe and M. Sabo (2008) Marketing of Hooves and Horns in Maiduguri Metropolitan Area of Borno State, Nigeria. Global Journal of Agricultural Sciences. 7 (2): 141-144

Mintesnot, H. D. A. (2016) Review on Contribution of Fruits and Vegetables on Food Security in Ethiopia. Journal of Biology, Agriculture and Healthcare 6(11):49-58

National Population Commission (NPC) (2006) Provisional Census

Parker, R.C. and Connor, J.M. (1979) Estimates for Consumer Loss Due to Monopoly in the U.S. Food Manufacturing Industries. American Journal of Agricultural Economics. 61: 626-639

Ruel, M.T., Minot, N and Smith, L. (2014) Patterns and Determinants of Fruit and Vegetable Consumption in SubSahara Africa: a Multi-Comparison. Background Paper for Joint FAO/World Health Organisation Workshop on Fruit and Vegetables for Health 1.3. September, 2014. Kobe, Japan. WHO, Geneva.

Yahaya, H. (2018) Nigeria produces less than 25 percent of local fruit juice demand-RMRDC. Daily Trust, July 22, p. 33. 